\title{
When Did God Create Hell?
}

\author{
Dr. Wycliffe Amukowa \\ Senior Lecturer, School of Education \\ Mount Kenya University, Kenya \\ Email:kwamukowa@yahoo.com
}

\section{Doi:10.5901/ajis.2013.v2n2p411}

\section{Abstract}

The concept of hell as a place for eternal punishment is a central theme in both Christianity and Islam. The followers of these religions believe that after the last judgment all wrongdoers (sinners) will be consigned to hell to suffer everlasting punishment, while non-sinners will go to heaven to enjoy a life of everlasting happiness (Mbugua 2011). This paper attempts a dismissal of the existence of Hell.

Keywords: Heaven, God, Sin, Hell, Punishment, Eternal

\section{Introduction}

According to Mbugua (2011), Hell is widely conceived in Christianity and Islam as a place created for punishment in which those who sin against God will go. In Christianity, hell is a place or a state in which the unsaved will suffer the consequences of sin for eternity. From the Christian perspective, Jesus teaches that:

\begin{abstract}
"If your hand causes you to sin, cut it off; it is better for you to enter life crippled, than, having your two hands, to go into hell, into the unquenchable fire (...) If your foot causes you to sin, cut it off; it is better for you to enter life lame, than, having your two feet, to be cast into hell (...) If your eye causes you to sin, throw it out; it is better for you to enter the kingdom of God with one eye, than, having two eyes, to be cast into hell (...) For everyone will be salted with fire" (Mark 9: 43-49 Holy Bible, New King James Version).
\end{abstract}

In Islam, hell (Jjahannam) is a place of eternal punishment for unbelievers. Hell is a place of endless punishment:

Surely (as for) those who disbelieve and act unjustly, Allah will not forgive them nor guide them to a path. Except the path of hell, to abide in it forever and this is easy to Allah (Qur'an 4: 168-169) (...)The truth is from your Lord, so let him who please believe, and let him who please disbelieve; surely We have prepared the iniquitous a fire, the curtains of which shall encompass them about; and if they cry for water, they shall be given water like molten brass which shall scald their faces; evil the drink and ill the resting place (Qur'an 18:29) (...) place of ambush, a resort for the rebellious. A dwelling place for the disbelievers. They will abide there forever. Therein they taste neither coolness nor any drink save boiling water and a fluid, dark, murky, intensely cold, paralyzing, a dirty wound discharge. It is a fitting reward for them (Qur'an 78:21).

Christianity and Islam use this idea of Hell to woe people into their respective religious practices on grounds that this will save them from eternal suffering. Arguing from Biblical citations, this paper challenges the existence of Hell.

\section{Genesis 1: The History of Creation}

From Genesis1:1 it is written that in the beginning, God created the heavens and the earth. We find that God has created only two forms, the heaven and the earth and there is no mention of Hell. In Genesis 1: 26:31, we find that man was created on the sixth day, which was also God's last working day. How then could God have created Hell to punish man who was not in existence?

Genesis2:2 informs us that:

(...) and on the Seventh day, God ended his work (...) (Holy Bible, New King James Version Genesis: 3:19). 
Genesis Chapter 1 informs us of all that God created on each day of his working. None of these days are we informed that God created Hell. This clearly shows that Hell is not God's creation. He ended His work on the seventh day and it would be untenable to suggest that he continued to create when He had finished His work. If therefore we entertain a belief in creation, then Hell does not exist.

\title{
3. Genesis 3: The Temptation and Fall of Man
}

In Genesis 3: 14-19, it is provided punishments that God administered to the Serpent, Eve and Adam for disobedience. Genesis 3: 14-15, so the Lord said to the serpent:

\begin{abstract}
"Because you have done this, you are cursed more than all cattle, and more than every beast of the field, on your belly you shall go, and you shall eat dust all the days of your life. And I will put enmity between you and the woman. And between you and her seed; He shall bruise your head, and you shall bruise His heel."
\end{abstract}

Genesis 3:16: To the woman He said:

"I will greatly multiply your sorrow and your conception; in pain you shall bring forth children; your desire shall be for your husband and he shall rule over you."

\section{Genesis 3: 17-19: To Adam He said}

\begin{abstract}
"Because you have heeded the voice of your wife, and you have eaten from the tree of which I commanded you, saying you shall not eat of it: Cursed is the ground for your sake; in toil you shall eat of it all the days of your life. Both thorns and thistles it shall bring forth for you, and you shall eat the herb of the field. In the sweat of your face you shall eat bread, till you return to the ground, for out of it you were taken, for dust you are, and to dust you shall return.
\end{abstract}

At this time, Adam and Eve have sinned, yet they are not sent to Hell or given a promise thereof, but their punishment is given on Earth. Adam's punishment is netted on him for all his life, till he returned to the ground. God does not give him an everlasting punishment upon returning to the ground. The same criterion applies to the punishment given to Eve and the Serpent. If Hell had been created at this time, then the two would have been sentenced into it. Here doubts are raised on whether Hell was created after the commitment of sin or before. This could be redundant because we are not told of another day, beyond the $6^{\text {th }}$ day that God created anything else. It is also seen that Hell exists, if so to speak, not on Earth and not in Heaven. So where is it?

It can also be seen from this chapter of the Bible that sin is committed after creation is complete. Therefore, if Hell came into being before man, then it implies establishing mechanisms to punish someone whose obedience has not been tested or his existence established. If God created Hell as a place of punishment before thinking of creating man, then Hell is not meant for man. How would God create a place to punish sinners without the sinners?

\section{John 1:3 Eternal World}

In John 1:3, it is stated that all things were made by Him, and without Him was not anything made that was made. This verse serves to the extent that God made everything and there cannot be anything that $\mathrm{He}$ did not make. Given the fact that Hell is not among the entities God created, as seen from the book of Genesis 1:1-31, then Hell does exist.

\section{Luke 16:19-31: The Rich Man and Lazarus: Is Hell in Heaven?}

Luke 16: 19-31 presents a case in which two people who lived different lives on earth have died, the rich man and Lazarus. On earth Lazarus was a beggar, but situations changed after death.

From Luke 16:22 it is written that:

So it was that the beggar died, and was carried by the angels to Abraham's bosom. The rich man also died and was buried. Luke 16:23: and being in torments in Hades, he lifted up his eyes and saw Abraham afar, and Lazarus in his bosom. 
Luke 16:24 then he cried and said,

Father Abraham, have mercy on me, and send Lazarus that he may dip the tip of his finger in water and cool my tongue, for I am tormented in this flame

Luke 16:25 But Abraham said,

Son, remember that in your life-time you received your good things, and likewise Lazarus evil things, but now he is comforted and you are tormented.

This is a scenario in which a person in Hell (if what the rich man is said to undergo is a representation of a situation in Hell) is having a conversation with those in Heaven. The proximity of the dwellings at this time raises questions on the location of Hell. How could the rich man have pleaded for a favour from Abraham to have Lazarus give him a drop of water? It appears here that one can just cross from Hell to Heaven and vice-versa. Abraham's reply indicates that there is a great gulf between the two that hinders movement.

Luke 16: 26:

And besides all this, between us and you there is a great gulf fixed, so that those who want to pass from here to you cannot, nor can those from there pass to us.

This reply by Abraham indicates that at some point, people in Heaven may want to cross to Hell. This raises questions as to why people who are in eternal happiness would want to cross to the side with eternal suffering. Assuming that probably those in eternal happiness are sympathetic to their loved ones in eternal suffering, then those in Heaven cannot be said to be happy as they are saddened by the experiences of their loved ones in Hell. It is also a wonder as of how the rich man did not notice the great gulf between them until Abraham brings to his attention.

It appears from this scenario that Hell is next to Heaven. However, we find from Genesis 1:1 that God created Heaven and no mention of Hell. How then did Hell get its location? From Genesis 1: 7, we find that after creating the heavens and the earth God made the firmament that divided the waters which were under the firmament from the waters which were above the firmament and it was so. In Genesis 1:8, God called the firmament, Heaven. There is no mention of the great gulf that divided Heaven and Hell. Neither from history of creation do we learn that God later partitioned Heaven to have room for Hell after man committed sin.

\section{Romans 16: 23. The Wages of Sin}

From Romans 16:23, the Bible teaches that the wages of sin is death, but the gift of God is eternal life through Jesus Christ. Here, the Bible contrasts death with eternal life and not eternal suffering and eternal happiness. It is not put that the wages of sin is eternal suffering but death. Death is not discussed in the Bible as a state of eternal suffering. Death is not equivalent of Hell.

\section{John 3:16. For God so Loved the World: Perish Versus Eternal Life}

John 3:16 provides that: (...) "For God so loved the world that He gave His only begotten son, that whosoever believes in him should not perish but have eternal life (...)" (Holy Bible, New King James Version, John 3:16)

In John 3:16, eternal life is contrasted with perish. For God so loved the world that he gave his only begotten son, that whosoever believeth in him should not perish, but have everlasting life. Here, we are not told of everlasting punishment, but perishing. Things that are perishable are not everlasting. Consequently, one cannot administer an everlasting punishment on a perishable entity. It is seen in this verse that Jesus came to bring eternal life and not end eternal suffering. John 3:16 conceives God as all loving to the extent of giving his only begotten son for the sake of man getting an everlasting life. As Mbugua (2011) wonders, how can such a God condemn his own creation to a life of endless suffering?

Checked against Genesis 3: 22-24, God did not intent that man lives forever. Here it is written that: 
from which he was taken. So he drove out the man and He placed cherubim at the east of Eden and a flaming sword which turned every way, to guard the way to the tree of life (...).(Holy Bible, New King James Version Genesis: 3: 2224)

As provided in John 3:16, the mission of Jesus Christ to the world is to bring eternal life to man, which God, as seen from the quotation above did not want man to have. But because God loved the world, he chose to give man eternal life. However, instead of eating from the tree of life, to be everlasting, man has to believe in Jesus Christ. It is seen here that man is driven out of Eden not because of the sin he had committed, but because God was guarding the tree of life that would have given man eternity.

\section{Conclusion}

John 1:3, re-affirmed: "all things were made by Him, and without Him was not anything made that was made". There being no substantive grounds to support the creation of Hell, this paper concludes that there is no Hell and such teachings are unfounded.

\section{References}

Mbugua, K. (2011). "The Problem of Hell Revisited: Towards a Gentler Theology of Hell". Thought and Practice: A Journal of the Philosophical Association of Kenya (PAK) New Series, Vol.3 No.2, December 2011, pp.93-103

The Holy Bible (Holy Bible, New King James Version). Thomas Nelson. Dallas.

The Holy Qur'an 